\title{
Recent Research Findings Related to Management Strategies of Begomoviruses
}

\author{
Snehi SK ${ }^{1 *}$, Raj SK ${ }^{2}$, Prasad V ${ }^{3}$ and Singh V ${ }^{1}$
}

${ }^{1}$ Department of Microbiology, Barkatullah University, Bhopal-462026, M.P., India

${ }^{2}$ Plant Molecular Virology Lab, CSIR-National Botanical Research Institute, Lucknow-226001, U.P., India

${ }^{3}$ Department of Botany, Molecular Plant Virology Lab, University of Lucknow, Lucknow-226007, U. P., India

\begin{abstract}
Begomoviruses (family Geminiviridae) cause a number of serious diseases of cultivated crops and they are considered as the major constrains for cultivation of several crops all over the world. Presently human activity and modern day agriculture are one of the key factors in the emergence of begomoviruses in various parts of the world. The available disease management options include the organisation of agricultural practice to reduce disease, the use of cultural control such as sanitation programmes, the control of the vector population through the use of insecticides, and the breeding and growing of resistant crop cultivars. Transgenic resistance against begomoviruses has shown limited success despite the use of a number of strategies. Ability of begomoviruses to evolve rapidly by recombination and mutations is the major limitation to all these strategies. In modern-day biotechnology, focus is required on engineering begomovirus resistance through transgenic approach. Expression of various full length or truncated or defective proteins of the virus has been effective in achieving pathogen-derived resistance. Antisense RNA and RNAi technology have also been used with some success. This review focus on both conventional and nonconventional management strategies methods have been suggested and described over the years for management of begomoviruses diseases in economically important plants.
\end{abstract}

Keywords: Begomovirus; Management strategies; Transgenic resistance; Antisense RNA; RNAi technology

\section{Introduction}

Begomovirus is the type species of Bean golden mosaic virus (BGMV) of the family Geminiviridae and it is transmitted through the whitefly (Bemisia tabaci Gennadius) in the persistent circulative manner. Begomoviruses infect dicots in tropical and temperate climates [1-4] and their genome consists of one or two circular single stranded DNA components, referred as DNA-A and DNA-B, each approximately $2.6-2.8 \mathrm{~kb}$ in size $[5,6]$. Begomovirus originating in the New World have a bipartite genome (DNA-A and DNA-B) organization whereas those from the Old World have either bipartite or monopartite (DNA-A) genomes [7]. In monopartite begomoviruses such as Tomato yellow leaf curl virus from Israel [8] and Sardinia [9], only a single component similar to DNA-A of bipartite begomoviruses in genome organization has been identified and shown to be enough for producing infectivity when reintroduced in tomato, fulfilling Koch's postulates and confirming that the single genomic component is solely responsible for disease development.

DNA-A is essential for replication and encapsidation [10-12] while DNA-B plays a role in systemic movement and symptom production $[13,14]$. The begomovirus replication cycles rely entirely on DNA intermediates and occur within the nucleus of the infected cell through two basic stages: conversion of ssDNA to dsDNA intermediates and rolling circle replication (RCR) [15].

DNA-A of all begomovirus has five ORFs, of which one (AV1, also called AR1) is on the virion DNA strand and the other four (AC1, AC2, $\mathrm{AC} 3$ and AC4 also designated as AL1, AL2, AL3 and AL4 respectively) are on the complementary strand. The viral strand ORFs code for the coat protein and for a protein required for cell-to-cell movement of the virus. The proteins encoded by the ORFs on the complementary strand are both involved in viral DNA replication, and are translated from spliced and unspliced versions of the same mRNA [16].
Begomoviruses from the Old World posses an additional ORF (AV2) does not found in New World begomoviruses. DNA-A has two ORFs in the virion sense or rightward direction [AV1/AR1-Coat protein (CP) and AV2/AR2-Pre coat protein] and four ORFs in the complementary sense or leftward direction [AC1/AL1-Replication initiator protein (Rep), AC2/AL2-Transcription activator protein (TrAP), AC3/AL3-Replication enhancer protein (REn), AC4/ AL4 and AC5/AL5]. DNA-B has one ORF each in virion strand or rightward direction [BV1/ BR1-Nuclear shuttle protein (NSP)] and complementary strand or leftward orientation [BC1/ BL1-Movement protein (MP) (Table 1).

DNA-A and DNA-B sequences are different from each other except for an approximately $200 \mathrm{bp}$ intergenic region (IR) [17] and hence that region is also called as common region (CR). The CR is present in the intergenic region between ORFs AV1 and AC1 in DNA-A and between ORFs BV1 and BC1 in DNA-B and it is highly specific for a virus. $\mathrm{CR}$ is the only region with significant sequences similarity between DNA-A and DNA-B components of the same virus. The CR has many regulatory element including two TATA motifs, one for ORF AV1/ AV2 and another for ORF AC1/AC4 (Table 1).

In few years satellite molecules called DNA- $\beta$ has been investigated to be associated with mono and bipartite begomoviruses and are

*Corresponding author: Snehi SK, 1Department of Microbiology, Barkatullah University, Bhopal-462026, M.P., India, Tel: 0755251 7100; E-mail: sunilsnehi@gmail.com

Received December 24, 2014; Accepted June 25, 2015; Published June 29 2015

Citation: Snehi SK, Raj SK, Prasad V, Singh V (2015) Recent Research Findings Related to Management Strategies of Begomoviruses. J Plant Pathol Microb 6: 273. doi:10.4172/2157-7471.1000273

Copyright: ( 2015 Snehi SK, et al. This is an open-access article distributed under the terms of the Creative Commons Attribution License, which permits unrestricted use, distribution, and reproduction in any medium, provided the original author and source are credited. 
Citation: Snehi SK, Raj SK, Prasad V, Singh V (2015) Recent Research Findings Related to Management Strategies of Begomoviruses. J Plant Pathol Microb 6: 273. doi:10.4172/2157-7471.1000273

Page 2 of 12

\begin{tabular}{|l|l|l|l|}
\hline ORF & Predicted molecular weight (kDa) & Putative protein & Predicted function \\
\hline AV1 & 30.0 & Coat protein (CP) & Encapsidation \\
\hline AV2 & 13.0 & Pre- coat protein & Cell to cell movement protein \\
\hline AC1 & 40.0 & Replication initiation protein (Rep) & Replication initiation \\
\hline AC2 & 17.0 & Transcription activator protein (TrAP) & Transcription activators of rightward ORFs, suppressor of PTGS \\
\hline AC3 & 15.0 & Replication enancer protein (REn) & Replication enhancement \\
\hline AC4 & 6.0 & - & Suppressor of PTGS, Viral replication \\
\hline AC5 & 18.0 & - & Viral replication \\
\hline BV1 & 29.0 & Nuclear shuttle protein & Nuclear trafficking (NSP) \\
\hline BC1 & 32.0 & Movement protein (MP) & Cell to cell movement, pathogenicity determinant \\
\hline
\end{tabular}

Table 1: ORF (Gene) order in begomovirus DNA-A and DNA-B components with their putative protein products and predicted function

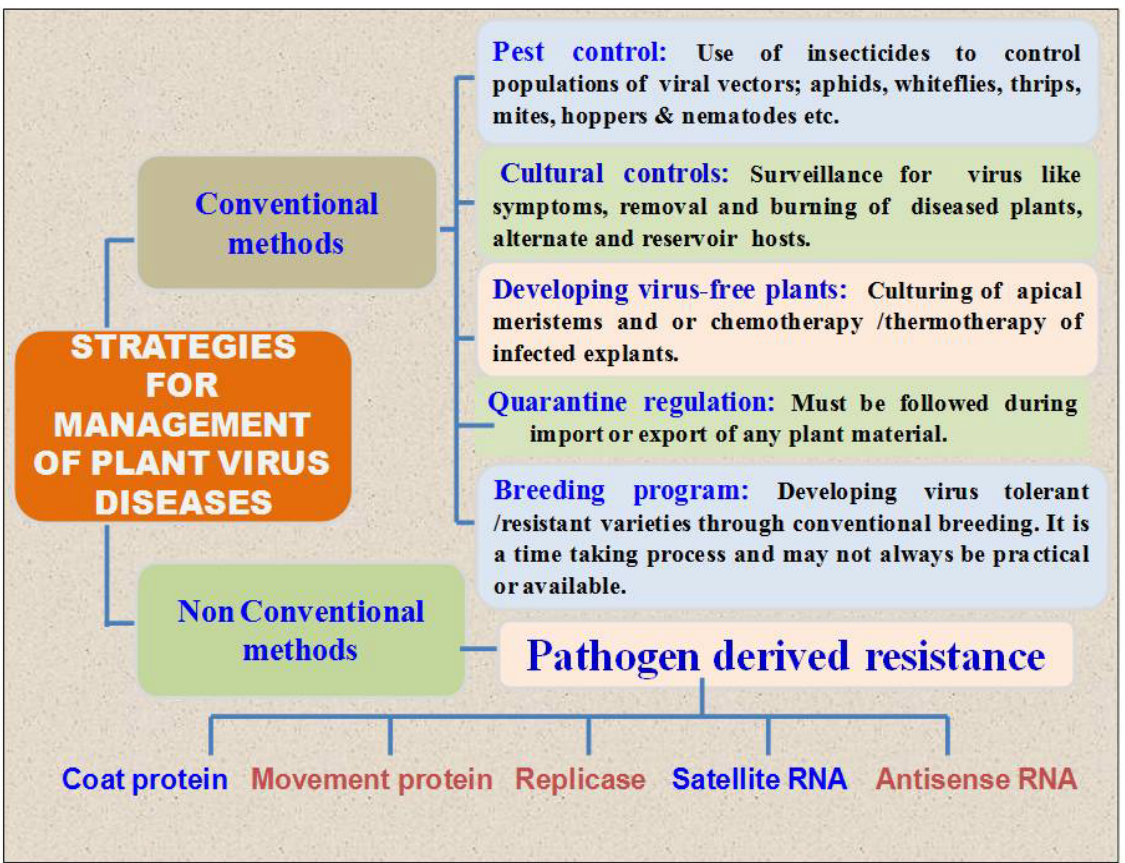

Figure 1: Figure showing strategies for management of plant virus diseases through conventional and non-conventional methods.

required for the systemic infection and symptom development [18-23]. Beside this there are a numerous report on a nanovirus like component, termed alphasatellites (DNA-1) found associated with the disease complex. DNA-1 components are related to nanovirus components that encode replication-associated proteins. So far they have not been shown to have essential role in the disease etiology. Alphasatellites can affect both begomovirus titer and symptom development in host plants [24,25]. Initially it was thought satellite molecules were limited to the Old World, but recently, alphasatellites have been found associated with New World begomoviruses [26,27], thus expanding the geographical distribution of satellite molecules associated with begomoviruses. Some alphasatellites encode a pathogenicity determinant that may modulate begomovirus-betasatellite infection by reducing betasatellite DNA accumulation [28].

Begomoviruses have emerged as more serious problems in a variety of economically important plants for example cassava, cotton, legumes, grain and vegetables [3]. Presently, begomoviruses are also associated with severe disease in tomatoes, okra, chilli, beans, cucurbits and weeds disease. In begomoviruses, the tendency for recombination and acquisition of extra DNA components had resulted in emergence of new viruses that infect new hosts and cause new diseases [3,29].
Therefore, virus management seems to be the only possibility to minimize the disease impact caused by these viruses. Availability of a sensitive diagnostic protocol for quick and reliable detection of these viruses at the early stage of infection in these plants will be the better choice.

\section{Management strategies of virus diseases}

Virus infected plants cannot be controlled or cured by any chemical treatment in the field [30]. However, they can be managed and therefore, control must be based on measures that prevent infection. Cultural practices such as rouging, intercropping, avoidance, use of barriers, crop residue disposal, among others, are recommended, but they should be combined with the use of insecticides and/or resistant varieties in order to be effective, especially in tropical areas, where tomato production occurs throughout the year [31-33]. Both conventional and non-conventional methods have been suggested and described over the years for control of viral diseases (Figure 1).

\section{Conventional measures}

The conventional measures are essentially based on cropping patterns and good agricultural practices. In several situations these 
are more than adequate to control or limit the transmission of the disease. However, in situations of severe epidemics or in situations where the crop has a genetic predisposition to be infected with the virus, non-conventional methods also need to be explored. Some of the conventional methods are first described in the following paragraphs.

\section{Use of healthy planting material and/or the eradication of infected plants}

Transplanting crops in greenhouses isolated from other plants that harbor or may harbor viral diseases e.g. susceptible crops, should be practiced [34]. Using planting material from which all infected plants have been removed (rouged), applying heat therapy $\left(35-54^{\circ} \mathrm{C}\right)$, use of meristem tip cultures, cold treatment and chemotherapy are other means suggested for obtaining virus free plants [35]. However, the major disadvantages of this approach encountered are difficulties in the detection of infected plants especially in countries which do not have the necessary infrastructure and agricultural extension services and the socio-economic difficulties of enforcing eradication schemes [36]

\section{Eliminating the weed hosts}

Weeds have been identified as key sources of viral infections for a long time. Murant and Taylor [37] reported that the over wintering nematode worms which lose their infectivity but regain it in the spring from germinating infective weed seeds, act as important source of virus infections. Cooper and Harrison [38] also studied the importance of vector nematodes in the distribution and activity of vector nematodes in the ecology of Tobacco rattle virus (TRV). They identified two weeds, Stellaria media and Viola arvensis as key overwintering hosts of TRV where the virus was found to be retained by the vector Trichodorus pachydermis for long periods. Eradication of perennial weeds from around greenhouses, gardens and fields to eliminate possible sources of virus therefore, may prove helpful [34]. For control of Cucumber mosaic virus (CMV), weed hosts harbouring cultivated fields has been found successful in reducing the incidences of virus in cucumber and celery [39]. However, such approaches have been reported to have their limitations and rather fail if there are changes that affect virus epidemiology such as local climatic fluctuations or changes in cropping practice [36].

Use of virus free planting materials, regular surveillance for disease symptoms at early stages of plants, followed by cleaning and removal of commonly growing weeds viz. Ageratum conyzoides, Acalypha indica, Croton bonplandianum, Eclipta prostrate, Physalis minima, Nicandra physaloides, Solanum nigrum, Datura stramonium, D. metel and other weeds (which act as potential reservoirs of begomovirus) from fields was found to be very effective.

Role of weeds/alternate hosts on the epidemiology of viral disease has been studied in case of many important viruses from India and abroad which are the major limiting factors to cultivation of important crops. In India, 13 weeds species have been identified to harbour Tomato leaf curl virus in Karnataka [40,41] recorded Sida sp. and Abutilon indicum as alternate hosts of Cotton leaf curl virus in Punjab. Valand and Muniyappa [42] reported 18 weed hosts of Tobacco leaf curl virus occurring in southern India. Nicotiana plumbaginifolia, Physalis minima, Coccinia grandis, Solanum nigrum, Momordica charantia (wild), Sorghum vulgare (widely growing) and Luffa spp. weeds have been found to be the hosts of geminivirus in north India [43]. In literature Croton bonplandianum to be the host of Tomato leaf curl New Delhi virus (ToLCNDV) and Parthenium hysterophorus was found to host of Tomato leaf curl Karnataka virus (ToLCKV) [22].
Alternate sources of Tomato leaf curl virus (ToLCV) or Tomato yellow leaf curl virus (TYLCV) have been found in many weed hosts. Dalmon and Marchoux in 2000 [44] reported that Solanum nigrum, Datura stramonium and Malva spp. could serve as reservoirs of TYLCV in France. In Spain numerous weed species viz. Chenopodium murale, Datura stramonium, Malva parviflora, Solanum nigrum, Convolvulus sp. and Cuscuta sp. were recorded to be the reservoirs of TYLCV [45] Recently Tomato leaf curl New Delhi virus (ToLCNDV) has been found associated with a common weed Eclipta prostrata in Pakistan [46], which is serious constraint of tomato, chilli and other crops on Indian subcontinent.

Therefore these weeds must be removed from and around the agricultural crop fields to minimize the source of reservoirs of many begomoviruses which also provide the shelter to whitefly, the known vector for transmission of a variety of begomoviruses.

\section{Management through chemical means to minimize the population of transmission vectors}

This comprises of controlling the vectors which act as carriers for transmitting the viruses from infected plant to the healthy ones. Avoidance by growing plants in isolated areas, early sowing of seeds, rotation of crops to reduce specifically soil-borne virus diseases, putting physical barriers like screens or cages to ward off insect vectors like aphids, leaf hoppers, whiteflies etc. are some of the strategies that have been suggested [47].

Killing the insect vectors by using insecticides is being used as early since 1930 s as a means of direct attack on vectors [48]. Bradbent et al. [49], tried several insecticides e.g. Endrin, Malathion, DDT etc. and showed successful prevention of Potato leaf roll virus (PLRV) spread from infected to healthy ones. However, excessive use of insecticides may also prove ecologically harmful in the long run. According to Hull and Davies [36], the use of insecticides to control aphid populations is neither realistic nor practical and since most of the early virus infections are initiated by insects feeding on perennial hosts, spraying for those hosts and weeds may be more helpful. Moreover, excessive use of insecticides may also prove ecologically harmful in the long run.

The development of strategies for integrated disease management by spray of oils, viricides, pesticides and botanicals has been found to be significant in reducing the yield loss by many workers for various viral diseases [50-57]. Three sprayings of Malathion (50\% E.C.) insecticide $(0.2 \%)$ at 21 days intervals was successful on various cultivars of chilli in field conditions to minimize the whitefly population and to assess the improvement of their biomass and ultimately the fruit yield. Three sprayings of Malathion insecticide $(0.2 \%)$ at 21 days intervals which were found to be best for minimizing the whitefly transmitted leaf curl disease of chilli cultivars is recommended for its possible management $[58,59]$. However, the regular use of insecticide should not be in practice because it adversely effects the environment, round other way, may diminish the quality of crops.

\section{Development or breeding of resistant varieties}

Developing plant varieties resistant against virus or its vector into the crop through breeding techniques is yet another approach for controlling viral diseases. Virus resistant crops increase profitability of production as they require no extra inputs to production of virusfree planting materials or control of virus vectors and because of the increases yields in quantity and quality both [30]. Though being the best of all the approaches, limitations to this conventional method of controlling virus diseases have been pointed out. For example, the 
resistance used by breeders is usually conferred by single dominant genes [60], the resistance conferred by which have been found to break down in the field [61]. Besides, desired resistance may not be always available in a closely related, infertile relative; the genes for resistance may be tightly linked to undesirable traits or the resistance may be multigenic and difficult to transfer. Large genome size, high amount of repetitive DNA and insufficient mapping of most of the plant species have also been suggested to make cloning of a host-encoded resistance gene very difficult. In addition, in majority of the cases, the mechanism underlying resistance to many important viruses in crop species has largely remained unknown and therefore no tag is easily available to identify and isolate these resistance genes $[30,62]$.

Resistance to tomato infecting begomoviruses has been successfully introgressed from Solanum pimpinellifolium, Solanum peruvianum, Solanum chilense and Solanum habrochaites [63]. From these sources, a few resistance genes have been well characterized and mapped using molecular markers. A partially dominant major resistance gene, Ty-1, was introgressed from S. chilense accession LA1969 and mapped to the short arm of chromosome 6 [64]. A major resistance QTL derived from S. pimpinellifolium (Hirsute-INRA) was mapped to a different position on chromosome 6 (TG153-CT83) [65]. Hanson et al. [66] mapped a dominant resistance gene, Ty-2, in S. habrochaites derived line $\mathrm{H} 24$, to the short arm of chromosome 11. A partially dominant major gene, Ty-3, derived from S. chilense (LA2779 and LA1932), was mapped to chromosome 6 [67]. The Ty-3 introgression derived from LA2779 was found to be longer and linked to Ty-1. However, recent studies on fine mapping and characterization demonstrated that Ty-1 and Ty-3 are allelic and code for an RNA-dependent RNA polymerase [68]. An additional gene, Ty-4, was mapped to the long arm of chromosome 3 . While Ty-3 has a major effect that accounts for $60 \%$ of the variation in symptom severity, Ty- 4 accounts for only $16 \%$ of the variation [69]. Recently, a recessive resistance gene (ty-5) was identified on chromosome 4 in the lines derived from cultivar Tyking [70], which is suspected to be similar to the Ty- 5 locus that accounts for more than $40 \%$ of the variation [71]. Most of these resistance sources are known to support virus replication. However, the level of virus accumulation is lower than the levels in susceptible cultivars. It is well established that the virus level in tomato lines carrying Ty-1/Ty- 3 is $<10 \%$ of the level found in susceptible cultivars [68]. Similarly, a low level of virus accumulation and a positive correlation between virus level and disease severity were found in Ty-2 carrying lines [72].

For virus resistance in particular, pyramiding has been achieved in different plant virus interactions e.g. Phaseolus vulgaris-Bean common mosaic virus (BCMV) [73], Capsicum annuum- Pepper veinal mottle virus (PVMV) [74], Hordeum vulgare-Barley mild mosaic virus (BaMMV) and Barley yellow mosaic virus (BaYMV) [75], and Glycine max-Soybean mosaic virus (SMV) [76]. Pyramiding of target genes can be achieved either by following a crossing or backcrossing scheme [77]. The reports introgressions that are known to confer resistance to Tomato leaf curl disease (ToLCD), such as ty-5 located on chromosome 4 [70] and qTy-10.1 (possible Ty-6) located on chromosome 10 [78].

Recently, Ty gene-linked markers were evaluated for their diagnostic value and utility in pyramiding Ty genes. Using these marker assays, $\mathrm{S}$. habrochaites derived resistance (Ty-2) and S. chilense derived resistance (Ty-3) were pyramided to develop a series of pyramided lines [79].

\section{Non-conventional measures}

The conventional methods for managing or controlling virus diseases have been found to possess their own drawbacks as pointed out earlier. Natural resistance to several important viruses is not known or breeding programs have failed to produce cultivars with effective resistance in a reasonable period of time. Development of virus resistant plants through genetic engineering has therefore emerged as the best strategy for management of viral diseases in the recent past.

The stable introduction of foreign genes into plant represents one of the most significant developments in a series of advances in agricultural technology that includes modern plant breeding, hybrid seed production, farm mechanization, and the use of agrichemicals to provide nutrients and control pests [80]. The major breakthrough in the management of viral diseases came when the first transgenic plants expressing engineered foreign genes were produced by the use of Agrobacterium tumefaciens vectors. Powell-Abel et al. [81] were the first to produce the genetically engineered virus resistance in tobacco plants. The coat protein $(\mathrm{CP})$ gene from Tobacco mosaic virus (TMV) was inserted into tobacco and the resultant transgenic plants were confirmed for the presence of foreign DNA sequence in both primary transformants and their progeny and the antibiotic resistance phenotype was conferred by a chimeric NPT II. The transgenics were constitutively found to express viral coat protein (CP) and more resistant to infection by TMV than were control non-transgenic plants [62]. This proved to be a major breakthrough in several ways. Along with engineered herbicide resistance and insect resistance using the Bacillus thuringiensis toxin gene, virus resistance was one of the first successes in the genetic engineering of a useful trait into plants [80]. Though the early transformation experiments often utilized plant protoplasts as the recipient cells; the subsequent development of transformation methods based on regenerable explants [82] such as leaves, stems and roots contributed significantly to the facile and routine transformation methods that are used today for many dicotyledonous plant species [80].

Genetically engineered resistance to viruses has been achieved in various plants either by the use of viral genes (known as the pathogen derived resistance or PDR) or through the expression of non-viral genes from different organisms, as under.

\section{Resistance conferred by viral genes (pathogen derived resistance)}

The work by Powell- Abel and his group in 1986 [81] opened new horizons for protection of plants against viral diseases and, during the last decade, a great number of publications showed that this concept could be applied to most plant viruses [36,62] Progress in the development of virus resistant transgenic plants (VRTPs) over the years has been extensively reviewed from time to time [83-85]. As of today, as many as 30 different virus groups have been utilized for which engineered resistance has been achieved utilizing different virus genes [86-94]. Genetic engineering has been proved to be highly effective for controlling virus diseases in a wide range of crops grown worldwide $[84,94,95]$.

The concept of inducing resistance to pathogens by transformation with genes derived from the genome of the pathogen, termed parasite or pathogen derived resistance, was first postulated by Hamilton in 1980 [96] and expanded to a generalized concept in 1985 by Sanford and Johnston [97]. The concept had its roots in empirically observed phenomenon of "cross protection" wherein inoculation of a host plant with a milder strain or symptomless strain of virus can protect the plant from infection by more severe strains of the same virus or very closely related viruses. Accordingly, it was postulated that the expression of a 
pathogen's own genes in a host in a dysfunctional form, in excess or at an inappropriate stage could disrupt the normal pathogenic cycle of the invading pathogen. Native or altered viral-derived genes might be used to interfere with various stages in the viral life cycle such as uncoating, replication, cell to cell or long distance movement or vector mediated transmission. Such interference with host-pathogen interactions renders the host resistant $[62,90]$.

Subsequently, the concept has been exploited to a substantial degree with a number of plant viruses by transforming with and expression of various virus derived genes or genome fragments [84,86,98-100]. Examples of viral genes that have been used or are being used are the coat protein, movement protein, replicase gene, antisense RNA, satellite RNA, defective interfering genes etc. all of which are derived from the genome of the virus. This is in contrast to the conventional breeding that necessarily relies on the host genes, which could be transferred between interfertile relatives [62]. In addition, to the limitations pointed out earlier to the use of conventional breeding techniques for obtaining virus resistant plants, other advantages were cited for the use of viral genes as a source of resistance genes over hostderived genes especially from a genetic engineering standpoint. These are the small genome size of viruses which could easily be identified, isolated and cloned fairly easily and the fact that genetic engineering provides a quicker and more precise technology to obtain plants that are resistant to viruses [62].

PDR conferred by Coat protein (CP) genes and Coat Protein mediated resistance (CPMR): The $\mathrm{CP}$ gene is the most widely and commonly used transgene for which virus resistant transgenic plants have been developed followed by replicase and the movement protein genes [94].

\section{Coat protein mediated resistance}

Coat protein mediated resistance"(CPMR) has been described as the resistance caused by the expression of a virus coat protein $(\mathrm{CP})$ gene in transgenic plants [83]. The initial demonstration of the feasibility of CP mediated protection in by Powell-Abel and group was followed by a host of examples. By the end of 1994 there were more than 50 published reports alone of genetically engineered $\mathrm{CP}$ mediated plant virus resistance in various systems belonging to at least 13 different groups for which resistance had been demonstrated. These included the plus sense, negative sense, single stranded and double stranded RNA viruses and at least one DNA virus [62]. By 1997, there were reports of CP genes from at least 35 viruses, representing 15 viral taxonomic groups that were transformed into many different plant species [97]. By 2002, this number further increased to $37 \mathrm{RNA} / \mathrm{DNA}$ viruses belonging to 17 virus groups [94].

Coat protein genes have been shown to be effective in preventing or reducing infection and disease caused by homologous and closely related viruses [95]. Some of the viruses against which the coat proteinmediated protection has been reported are Tobacco mosaic virus (TMV) [101]; Tomato mosaic virus (ToMV) [102]; Cucumber mosaic virus (CMV) [103-105]; Alfalfa mosaic virus (AlMV) [106,107]; Potato virus X (PVX) [108]; Potato virus Y (PVY) [109] and Potato leaf roll virus (PLRV) [110] and the only report of engineered resistance to a geminivirus using the coat protein gene was by Kunik et al., [111], which reported that resistance to TYLCV was associated with the presence of the transgene product.

The expression of viral coat protein (CP) genes in transgenic plants can lead to different phenotypes of resistance. Assessment of disease resistance involves inoculating transgenic plants that express the transgene $[\mathrm{CP}(+)$ gene or other viral gene in consideration] and those that do not $[\mathrm{CP}(-)]$ with virus and comparing the numbers of infection sites and/or the development of disease symptoms on the two types of plants. Preferably, R1 or successive generations of plant populations are used as they are identical in age, growth rate and size. Segregation of the introduced gene in the progeny can be followed immunologically using antibodies to $\mathrm{CP}$ or by following the expression of a reporter gene (e.g. NPT II gene for Kanamycin resistance) that is co-introduced with the transgene [83].

Studies on transgenics over the years indicate that the mechanism of protection is not similar in every virus-CP-host combination [62]. Different mechanisms appear to be responsible for protection, depending on the virus group or the viral transgene studied [86]. Pathogen-derived resistance has been observed to be mediated either by the protein encoded by the transgene (protein-mediated) or by the transcript produced from the transgene (RNA-mediated) also known as post transcriptional gene silencing (PTGS) or both [94].

\section{Protein-mediated resistance}

Coat protein $(\mathrm{CP})$ gene induced resistance is protein-mediated when a single copy of transgene is inserted. Transgene undergoes transcription and translation, resulting in high levels of protein [94]. Resistance so expressed is of moderate level against a broad range of related viruses and influenced by the level of CP expressed in transgenic plants. It was initially assumed to be similar to the phenomenon of cross-protection, with $\mathrm{CP}$ interfering with the uncoating of virions and inhibiting both the establishment of infections and the spread of virus from cell to cell $[83,112]$. For Tobacco mosaic virus (TMV), Alfalfa mosaic virus (AlMV), Potato virus X (PVX) and Rice stripe virus, the level of protection was found to be directly related to the level of transgenic coat protein accumulated in transgenic plants $[81,106,108,113]$. Interference with early events in infection, such as an inhibition of virus uncoating by the transgenic coat proteins, was proposed as a key component to explain the protection [114,115]. The protoplasts of TMV or AlMV-CP (+) plants inoculated with whole virions were protected against the infection but if they were inoculated with naked viral RNA they were not protected [116]. Plants that accumulated coat protein messenger RNA and not the coat protein itself (e.g. constructs with initiation codon removed) were not resistant to infection [117].

\section{RNA-mediated resistance}

$\mathrm{CP}$ gene induced resistance is RNA-mediated when multiple copies of transgene are inserted [86]. Resistance so expressed has been observed to be of high level and strain specific and attributed to lower levels of transcripts. Transgene expression is upto mRNA level with little or no transgenic protein. When mRNA accumulation exceeds a threshold level, co-suppression (gene silencing) is initiated, affecting transgene expression and virus multiplication [94]. For virus suppression to occur, it was necessary that the viral genome have some sequence identity to the transgene $[118,119]$. The phenomenon has been termed as the post-transcriptional gene silencing or PTGS [119]. This virus resistance mechanism was referred to as homologydependent virus resistance to reflect the relationship with homology dependent gene silencing [120]. The defense system exhibited by such plants results in the degradation of mRNA produced both by the transgene and the infecting virus [121]. A lack of correlation between resistance and the expression level referred to as RNA mediated. It is also characterized by a lack of dependence upon inoculums dose and a narrow spectrum of protection. 
That resistance shown by some transgenic plants to virus infection was RNA-mediated and not by the protein expressed by transgene came from several reports and against several groups of viruses. It was shown for viruses belonging to families, such as Potato virus $Y$ (PVY), carla-, nepo-, luteoviruses, PLRV or TSWV and ToMoV, a geminivirus, that the resistance did not correlate with the accumulation of coat protein (or nucleocapsid protein) in the transgenic plants [122124]. Virus resistance was found to be inversely correlated with the steady state levels of transcripts in the transgenic plants [86]. Highly resistant transgenic lines were identified in which the coat protein was undetectable indicating that the protection conferred by the CP gene was partially or completely due to the viral-derived RNA rather the $\mathrm{CP}$. Some other step in addition to interference with uncoating was suggested to be affected.

Transgenic cassava plants have been developed against a begomovirus, African cassava mosaic virus (ACMV) to express small interfering RNAs (siRNA) from intron-containing dsRNA cognate to the common region-containing bidirectional promoter of ACMV DNA-A [125].Virus resistant transgenic common bean (Phaseolus vulgaris) plants have developed using RNAi construct to silence the sequence region of the AC1 viral gene [126]. TLCV-Au resistant Nicotiana tabaccum plants have been developed using a betasatellite/ split intact barnase gene construct, with the optimal direct repeat unit of the barnase gene [127]. The biosafety is an important issue against the development of virus resistant transgenic plants as there is possibility of plant viruses may recombine to produce new strains that may express novel phenotypes and virus resistant transgenes may be transmit by pollen to other non-transgenic plants.

\section{Pathogen-derived resistance (PDR) conferred by other viral genes-replicase gene}

Apart from coat protein, resistance to viral infection mediated by the expression of functional or altered replicase genes in transgenic plants (replicase mediated resistance) is the second most widely used method for controlling virus diseases of plants $[86,97,119,128]$. Since its first demonstration in Tobacco mosaic virus (TMV) [129], it has been successfully used from 16 RNA/DNA viruses representing 11 plant virus groups [94,97]. Constructs that have been used or are being used include replicase read-throughs as well as full length, truncated or mutated replicase genes. Two examples of virus-encoded, replication related genes inducing resistance in plant geminiviruses namely African cassava mosaic [130] and Tomato yellow leaf curl [131] have also been reported [97].

Replicase mediated resistance has been characterized by resistance to inoculation with high concentrations of virus but has been found to be specific to the virus from which the transgene is derived and to closely related strains [128]. Although, replicase mediated resistance has been demonstrated for several viruses, Palukaitis and Zaitlin, [97] have commented upon several incidences where breakage of resistance been demonstrated like Pepper mild mottle virus [132]; Cucumber mosaic virus [133,134]; Potato virus $X[135]$ and Potato virus $Y$ [136] and the one report from geminivirus i.e. African cassava mosaic virus [130].

Regarding mechanism of replicase mediated resistance, two types of mechanisms were proposed by Palukaitis and Zaitlin [97] as for CPMR (i) in some cases the resistance was found to be protein mediated e.g. AlMV [137] and TMV [138] where the resistance shown by transgenic plants was directly correlated with the expression the transgene protein while in other cases, (ii) resistance correlated inversely with accumulation of transgenic RNA e.g. PVX [120] and CymRSV [139].

\section{PDR conferred by other viral genes-movement protein gene}

Cell to cell movement of plant viruses in host plants has been associated with the movement protein [140] encoded by viruses. MP interacts with the plasmodesmata thus modifying it to facilitate cell to cell movement of plant viruses [141,142]. Interfering with cell to cell or long distance movement of plant viruses by using defective movement proteins has been demonstrated for at least six different groups of viruses [94]. Cooper et al. [143] showed broad spectrum resistance in transgenic tobacco expressing defective Tobacco mosaic virus movement protein (TMV MP) against a number of viruses including AlMV, CMV, TRV, PCSV and TRSV. Likewise, Tacke et al. [144] produced transgenic potato expressing mutant PLRV of 17 MP, resistant against unrelated viruses PVY and PVX. However, with TSWV, transgenic plants were found to be effective against TSWV strains only indicating variability in cell to cell movement amongst viruses of different groups [94].

In addition, satellite virus RNA and defective interfering RNAs [145-147]; proteases [148,149]; virus antisense RNA [150,151] and ribozymes [84,152-154] have also been engineered into plants to obtain virus resistance in different crops.

\section{By RNA silencing}

RNA silencing involves suppression of gene expression by sequence specific degradation of mRNA in diverse eukaryotes. The RNA silencing phenomena was first discovered and termed post transcription gene silencing (PTGS) in plants [155], quelling in fungi [156] and RNA interference (RNAi) in animals $[157,158]$.

Key molecules involved in the RNA silencing pathways are ribonuclease Dicer (RNA-dependent RNA polymerase, RDR), and argonaute (AGO). The RNA silencing machinery in plants are more evolved than in fungal and animal systems. The Arabidopsis genome encodes four Dicer like (DCL) enzymes, six RDRs and 10 AGO proteins.

There are three different pathways in the gene silencing mechanism:

(i) Cytoplasmic short interfering (siRNA) silencing.

(ii) Silencing of endogenous mRNAs by micro RNAs (miRNAs).

(iii) DNA methylation and suppression by transcription [159]. siRNA silencing is actually post transcriptional gene silencing (PTGS) which was first identified by Bisaro in 2006 [160]. This mechanism results in the production of 21-25 nucleotide siRNA which are generated by inducing dsRNA [161] leading to the degradation of mRNA.

\section{Engineered resistance against begomoviruses}

The coat protein protection was reported to be successful against several RNA viruses; however, few reports of engineered resistance against geminiviruses have also been reported. Kunik et al. in 1994 [111] extended the concept of capsid protein mediated protection, which has been applied successfully with many RNA viruses, to the DNA geminivirus, Tomato yellow leaf curl virus (TYLCV) [111].

Success has been reported with expression of other geminivirus transgene modified and unmodified like replication- associated protein (Rep), and movement protein gene. Day et al. [162] reported the use of antisense RNA to the rep protein gene as the transgene for resistance against Tomato golden mosaic virus (TGMV). They introduced the antisense of rep gene under the influence of CaMV $35 \mathrm{~S}$ promoter in a genetic cassette. This cassette, when introduced into Nicotiana 
tabaccum rendered plant resistant to the virus. They obtained various lines that showed resistance. Bendahmane and Gronenborn [163] used the antisense RNAs, to Rep protein gene, to interfere with the disease caused by Tomato yellow leaf curl virus (TYLCV). In this case a double-enhanced CaMV $35 \mathrm{~S}$ promoter was used to derive the synthesis of antisense RNA to the Rep protein gene. A number of plants were found to have resistance against the virus in R2 generation. Expression of the defective Rep protein in transgenic plants has also been shown to interfere with the replication of TYLCV [131]. They used a truncated form of the gene, capable of expressing the $\mathrm{N}$-terminal 210 amino acids (of the 359 amino acids encompassed by the wild type Rep protein) of the Rep protein under the influence of CaMV $35 \mathrm{~S}$ promoter. The transformed tobacco $(N$. benthamiana) plants when challenged with the virus, showed various degree of resistance against the virus.

By expressing the coat protein gene in tomato (Lycopersicon esculentum) they obtained resistance against TYLCV. In the resistant plants expression of the viral DNA and of disease symptom was delayed by approximately one month. These plants recovered from the disease and symptoms as well as viral DNA disappeared completely 4 months after the inoculation. Recently, Agrobacterium mediated tomato transformation was attempted for regeneration of transgenic tomato plants expressing Tomato leaf curl virus coat protein gene (TLCV-CP). The generated transgenic plants when challenged by TLCV through whiteflies, showed variable degrees of disease resistance/tolerance against TLCV infection [164].

There have been several efforts to achieve resistance against mungbean infectin g begomoviruses. Mungbean yellow mosaic virus MYMV-Vig transgenes (CP, Rep, Rep-antisense, truncated Rep, NSP and MP) were evaluated in transgenic tobacco ( $N$. tabacum ) by agroinoculation. Unexpectedly, the transgenic tobacco plants harboring CP and MP ORFs accumulated even higher levels of viral DNA. However, viral DNA accumulation was inhibited in one transgenic plant harbouring the Rep (sense orientation) and in two plants harbouring the antisense-Rep ORF [165].

A convenient transgenic system to evaluate MYMV DNA replication is tobacco leaf disc, in which the replication of the viral DNA can be easily monitored. Leaf discs of transgenic tobacco plants expressing truncated TrAP gene of MYMV at various levels showed a reduction in DNA accumulation, in proportion to the levels of transgene expression. Expressing the ssDNA binding protein VirE2 of A. tumefaciens in the above system also reduced viral DNA accumulation [166], which can be used as a promising tool to impart resistance against more than one geminiviurses.

To understand the molecular mechanism of natural resistance, distribution of MYMIV-derived siRNAs was analysed in a resistant variety of soybean. It was found that most of the virus-derived siRNAs were complementary to the IR in the resistant variety, while in the susceptible variety, a majority of the siRNAs corresponded to coding regions of the viral genome. Most of the IR-specific siRNA molecules produced in the resistant plants were $24 \mathrm{nt}$ in size and a higher level of methylation occurred in the IR of viral DNA [167].

In a recent effort to confer resistance against geminiviruses infecting papaya, siRNAs were designed using computational tools, which could possibly be used against a wide spectrum of viral isolates and/or strains [168].

A great effort has been made to obtain genetic resistance to begomoviruses, with much of it directed against TYLCV. Several groups of researchers have looked for TYLCV resistance and tolerance among wild Lycopersicon species and have found some promising materials within $L$. chilense Dun., L. pimpinellifolium (Jusl.) Mill., $L$. hirsutum Dun., L. cheesmani Riley, and L. peruvianum (L.) Mill. [169173], among others. Some accessions of tomato wild relatives exhibited good levels of resistance and tolerance to bipartite begomovirus as well, such as Tomato yellow mosaic virus [174] and the $\mathrm{DF}_{1}$ isolate $[175,176]$

Transgenics carrying antisense sequence of Rep gene was shown to recover from ToLCD $[177,178]$. In a biosafety analysis, the above transgenics were shown to be non-toxic to mice [179], thereby making the product easily acceptable to consumers. In another effort for engineering resistance, targeting the conserved regions in AC1 / Rep (overlapping sequences of the AC4 ORF) with hairpin-mediated strategies was shown to be a promising means to suppress a wide spectrum of ToLCVs infection in tomato [180]. In a recent study, multiple siRNAs were designed using computational tools, which could possibly be used against a wide spectrum of ToLCVs [168].

Virus-induced gene silencing (VIGS) vector are useful tools for the study of gene functions in plants. A VIGS vector, spanning the intergenic region and the AC3 had been constructed from ToLCV, which was shown to successfully silence endogenous plant gene, PCNA. It was also shown that a mutation in the AC3 (a putative silencing suppressor) can increase the silencing efficiency several folds [181].

\section{Suppression of post transcriptional gene silencing of Betasatellite}

Geminiviruses are both inducers and targets of PTGS. Virusderived small-interfering (si) RNAs can be found in cells after infection of plants [182], and the levels of the siRNAs are negatively correlated with symptom severity [183].

To counteract host defense systems, geminiviruses have evolved suppressors of RNA silencing [184]. Like many other viral pathogenicity determinants, the $\beta C 1$ proteins can function as RNA silencing suppressors. The reported $\beta \mathrm{C} 1$ suppressors include TYLCCNB- $\beta \mathrm{C} 1$, CLCuMuB- $\beta C 1$, and $\beta C 1$ proteins of betasatellites associated with Bhendi yellow vein mosaic virus (BYVMV), Tomato leaf curl Java virus (ToLCJAV), and Tomato leaf curl China virus (ToLCCNV) [185-189].

The TYLCCNB- $\beta C 1$ protein can bind single-stranded (ss) DNA and double-stranded (ds) DNA in vitro in a sequence nonspecific fashion, and a $\beta C 1$ nuclear localization motif is required for suppressor activity [186]. Nuclear localization of the $\beta C 1$ protein of Tomato leaf curl China betasatellite is absolutely indispensable for silencing suppression, and the central portion of $\beta \mathrm{C} 1$ (amino acids 44 to 74 ) is critical for suppression silencing and nuclear localization [189]. The CLCuMuB- $\beta C 1$ protein has substantial nucleic acid binding activities that include DNA binding, dsRNA binding, and both long and short RNA binding with preferences for long RNAs $[185,190]$. CLCuMuB$\beta C 1$ is also capable of suppressing systemic gene silencing, and coinoculation of CLCuMuB- $\beta C 1$ with a heterologous helper virus, ToLCV, resulted in reduced levels of ToLCV siRNAs. It is possible that the $\mathrm{CLCuMuB}-\beta \mathrm{C} 1$ protein blocks the long-distance spread of PTGS signals by sequestering dsRNAs and/or siRNAs and preventing their incorporation into RNA-induced silencing complexes [191,192].

\section{Conclusions}

The virus diseases cannot be controlled by any chemical treatment in the field [30]. However, they can be managed based on strategies that prevent infection. Both conventional and non-conventional methods have been suggested and described over the years for management of viral diseases. 
In recent years, the begomovirus has received a great deal of attention and is becoming one of the most important and studied genus of plant virus. Begomoviruses are of importance in the tropics and subtropics due to climatic factors favoring the multiplication and ability of vector i.e. whitefly (B. tabaci) for transmitting the begomovirus to other economic crops. The incidence and severity of the disease may be increasing due to the emergence of new begomoviruses through recombination or pseudo-recombination among strains and/or species in various crops $[3,29]$. The association of satellite molecule called DNA- $\beta$ with both monopartite as well as bipartite begomoviruses are the other major factor which role in disease severity have been studied by many virologist in various crops [18-20].

Begomoviruses are transmitted by different whitefly vectors (which are a serious pest) and many can also be transmitted by mechanical means and grafting, but they are not seed transmitted. Begomovirus control is particularly difficult in open field crops due to the widespread presence, wide host range and population of whiteflies. Disease management may include pathogen exclusion, vector control, and elimination of pathogen alternate host/virus reservoir and vector reservoir plants. In some cases, crop cultivars with increased virus resistance are available. The traditional genetic resistance, chemical controls and cultural practices for successful control of viruses may be adopted.

There are several methods such as field sanitation, eradication of infected plants serving as primary source of virus inoculum, removal of weeds and alternate host plants from of fields, plantation practices, spraying of insecticides, use of virus free planting material and resistant varieties are suggested to be practiced/ applied for control of begomovirus and its whitefly vector. The traditional host genetic resistance, chemical controls and cultural practices may also be adopted for successful control of virus disease.

The development of strategies for integrated disease management by spray of oils, viricides, insecticide/pesticides and botanicals has been found to be significant in reducing the yield loss.

$>$ Weeds have been identified as key sources of viral infections for a long time. Eradication of perennial weeds from around greenhouses, gardens and fields to eliminate possible sources of virus therefore may prove helpful [34]. Several weed have been reported to be the natural reservoir of begomovirus [58]. Therefore, such weed plants may be eliminated from and nearby cultivated fields for possible management of begomoviruses. Immediate removal of infected individual plants may assist in delaying virus spread. The infected material is may immediately destroyed and not left to compost near adjacent to developing fields.

Development of sensitive diagnostic protocol is essential to search the begomovirus in cultivated crops and other alternate hosts. Since nucleotide sequence data of the coat protein $(\mathrm{CP})$ gene region has been considered as a major characterizing factor for a number of begomoviruses by the ICTV.

Genetically engineered resistance to viruses has been achieved in various plants by the use of viral genes is known as the pathogen derived resistance or PDR. Genetic engineering has been proved to be highly effective for controlling virus diseases in a wide range of crops grown worldwide. The coat protein protection was reported to be successful against several RNA viruses however; few reports of engineered resistance against geminiviruses have also been reported. Kunik et al. [111] extended the concept of capsid protein mediated protection, which has been applied successfully with many RNA viruses, to the DNA geminivirus, TYLCV and CP gene of ToLCV has also been utilized to generated transgenic lines of tomato. These lines successfully express CP gene and showed significant level of resistance against challenge inoculation of ToLCV. Therefore, CP gene mediated resistance has also been proved against ToLCV in tomato in India [164]. Success has been reported with expression of other geminivirus transgene modified and unmodified like replication- associated protein (Rep), and movement protein gene. The use of antisense AC1 genes has been shown to confer resistance to Tomato golden mosaic virus by transgene expression and accumulation of the product [162] whereas in TYLCV resistance was conferred due to a dominant negative mutation [163].

\section{Acknowledgement}

Authors are thankful to Vice Chancellor, Barkatullah University, Bhopal for facilities and keen interest.

\section{References}

1. Brown JK, Czosnek H (2002) Whitefly transmitted viruses. In: Advances in Botanical Research, Academic Press, NewYork. 65-100.

2. Jones DR (2003) Plant viruses transmitted by whiteflies. Eur J Plant Patho 109: 195-219.

3. Varma A, Malathi VG (2003) Emerging geminivirus problems: A serious threat to crop production. Ann App Biol 142: 145-146.

4. Brown JK (2010) Phylogenetic biology of the Bemisia tabaci sibling species group. Chapter 2 In: P. A. Stansly and S. E. Naranjo (Eds.), Bionomics and Management of a Global Pest. Springer Science, The Netherlands 31-67.

5. Stanley J, Bisaro DM, Briddon RW, Brown JK, Fauquet CM, et al. (2005) Geminiviridae. In: Fauquet, C.M., Mayo, M.A. Maniloff, J. Desselberger, U. and Ball, L.A. (Eds.), Virus Taxonomy, VIIIth Report of the ICTV. Elsevier/Academic Press, London, 301-326.

6. Fauquet CM, Briddon RW, Brown JK, Moriones E, Stanley J, et al. (2008) Geminivirus strain demarcation and nomenclature. Arch Virol 153: 783-821.

7. Brown JK, Idris AM, Alteri C, Stenger DC (2002) Emergence of a new cucurbit infecting begomovirus species capable of forming viral reassortant with related viruses in the Squash leaf curl virus cluster. Phytopathol 92: 734-742.

8. Navot N, Pichersky E, Zeidan M, Zamir D, Czosnek H (1991) Tomato yellow lea curl virus: a whitefly-transmitted geminivirus with a single genomic component. Virology 185: 151-161.

9. Kheyr-Pour A Bendahmane M, Matzeit V, Accotto GP, Crespi S, et al. (1991) Tomato yellow leaf curl virus from Sardinia is a whitefly-transmitted monopartite geminivirus. Nucleic Acids Res 19: 6763-6769.

10. Rogers SG, Bisaro DM, Horsch RB, Fraley RT, Hoffmann NL, et al. (1986) Tomato golden mosaic virus A component DNA replicates autonomously in transgenic plants. Cell 45: 593-600

11. Townsend R, Watts J, Stanley J (1986) Synthesis of viral DNA form in Nicotiana plumbaginifolia protoplast inoculated with cassava latent virus (CLV): evidence for the independent replication of one component of CLV genome. Nucl Acid Res 14: 1253-1265.

12. Sunter G, Gardiner WE, Rushing AE, Rogers SG, Bisaro DM (1987) Independent encapsidation of tomato golden mosaic virus A component DNA in transgenic plants. Plant Mol Biol 8: 477-484.

13. Etessami P, Callis R, Ellwood S, Stanley J (1988) Delimitation of essentia genes of cassava latent virus DNA 2. Nucleic Acids Res 16: 4811-4829.

14. Noueiry AO, Lucas WJ, Gilbertson RL (1994) Two proteins of a plant DNA virus coordinate nuclear and plasmodesmal transport. Cell 76: 925-932.

15. Gutierrez C (2002) Strategies for geminivirus DNA replication and cell cycle interference. Phys Mol Plant Pathol 60: 219-230.

16. Harrison BD, Robinson DJ (2002) Green shoot of geminivirology. Phys Mol Plant Pathol 60: 215-218.

17. Padidam M, Beachy RN, Fauquet CM (1995) Classification and identification of geminiviruses using sequence comparisons. J Gen Virol 76 : 249-263.

18. Saunders K, Bedford ID, Briddon RW, Markham PG, Wong SM, et al. (2000) 
Citation: Snehi SK, Raj SK, Prasad V, Singh V (2015) Recent Research Findings Related to Management Strategies of Begomoviruses. J Plant Pathol Microb 6: 273. doi:10.4172/2157-7471.1000273

A unique virus complex causes Ageratum yellow vein disease. Proc Natl Acad Sci U S A 97: 6890-6895.

19. Briddon RW, Mansoor S, Bedford ID, Pinner MS, Saunders K, et al. (2001) Identification of dna components required for induction of cotton leaf cur disease. Virology 285: 234-243.

20. Jose J, Usha R (2003) Bhendi yellow vein mosaic disease in India is caused by association of a DNA Beta satellite with a begomovirus. Virology 305: 310-317.

21. Rouhibakhsh A, Malathi VG (2005) A severe leaf crinkle disease of cowpea caused by Mungbean yellow mosaic India virus and a satellite DNA- $\left.\right|^{2}$. Plant Pathol 54: 259

22. Reddy RV, Colvin J, Muniyappa V, Seal S (2005) Diversity and distribution of begomoviruses infecting tomato in India. Arch Virol 150: 845-867.

23. Tahir M, Haider MS (2005) First report of Tomato leaf curl New Delhi virus infecting bitter gourd in Pakistan. Plant Pathol 54: 807

24. Saunders K, Stanley J (1999) A nanovirus-like DNA component associated with yellow vein disease of Ageratum conyzoides: evidence for interfamilial recombination between plant DNA viruses. Virology 264: 142-152.

25. Patil BL, Fauquet CM (2010) Differential interaction between cassava mosaic geminiviruses and geminivirus satellites. J Gen Virol 91: 1871-1882.

26. Paprotka T, Metzler V, Jeske H (2010) The first DNA 1-like alpha satellites in association with New World begomoviruses in natural infections. Virology 404 148-157

27. Romay G, Chirinos D, Geraud-Pouey F, Desbiez C (2010) Association of an atypical alphasatellite with a bipartite New World begomovirus. Arch Virol 155: 1843-1847.

28. Idris AM, Shafiq SM, Briddon RW, Khan AJ, Zhu JK, Brown JK (2011) An unusual alphasatellite associated with monopartite begomoviruses attenuates symptoms and reduces betasatellite accumulation. J Gen Virol 92: 706-717.

29. Chakraborty S, Pandey PK, Banerjee MK, Kalloo G, Fauquet CM (2003) Tomato leaf curl Gujarat virus, a New Begomovirus Species Causing a Severe Leaf Curl Disease of Tomato in Varanasi, India. Phytopathology 93: 1485-1495.

30. Valkonen J (1998) Virus disease control in plants using natural and engineered resisitance and some consideration regarding biosafety. Currents 17: 51-55.

31. Polston JE, Anderson PK (1997) The emergence of whitefly transmitted geminiviruses in tomato in the western hemisphere. Plant Dis 81: 1358-1369.

32. Faria JC, Zerbini FM (2000) FamÃlia Geminiviridae $3 / 4$ taxonomia replicaÃßÃ £o e movimento. RevisÃ£o Anu de Patologia de Plant 8: 27-57.

33. Hilje L, Costa HS, Stansly PA (2001) Cultural practices for managing Bemisia tabaci and associated viral diseases. Crop Prot 20: 801-812.

34. Agrios GN (1978) Plant Pathology. (2ndedn) Academic Press, Inc., San Diego, California. 466-470.

35. Raychaudhuri SP, Verma JP (1977) Therapy by heat, radiation and meristem culture, In â€œPlant diseases-an advanced treatiseâ€. JG Horsfall and EB Cowling (Eds.), Academic Press, New York. Vol. 1.

36. Hull R, Davies JW (1992) Approaches to non-conventional control of plant virus diseases. Crit Rev Plant Sci 11: 17-33.

37. Murant AF, Taylor CE (1965) Treatment of soils with chemicals to prevent transmission of tomato black ring and raspberry ring spot viruses by Longidorus elongatus (de Man). Ann Appl Biol 55: 227-237.

38. Cooper JI, Harrison BD (1973) The role of weed hosts and the distribution and activity of vector nematodes in the ecology of tobacco rattle virus. Ann Appl Biol 73: 53-66.

39. Rist DL, Lorbeer JW (1989) Occurrence and overwintering of Cucumber mosaic virus and Broad bean wilt virus in weeds growing near commercial lettuce fields in New York. Phytopathol 79: 65-69.

40. Ramappa HK, Muniyappa V, Colvin J (1998) The contribution of tomato and alternative host plants to Tomato leaf curl virus inoculums pressure in different areas of South India. Ann App Biol 133: 187-198.

41. Singh J, Sohi AS, Mann HS, Kapoor SP (1994) Studies on whitefly Bemisia tabaci (Genn.) transmitted cotton leaf curl virus disease in Punjab. J Insect Sci 7: 194-198.

42. Valand GB, Myniyappa V (1992) Epidemiology of tobaco leaf curl virus in India. Ann Appl Biol 120: 257-267.
43. Khan MS, Raj SK and Singh BP (2003) Some weeds as new hosts of Geminivirus as evidenced by molecular probes. Indian J Plant Pathol 21: 82-85.

44. Dalmon A, Marchoux G (2000) Quelles plantes hÃ'tes pour le Tomato yellow leaf curl virus?. Phytoma la DÃ@fense des VÃ@gÃ@taux 527: 14-17.

45. Jorda C, Font I, Martinez P, Juarez M, Ortega A (2000) Current status and new natural hosts of tomato yellow leaf curl virus (TYLCV) in Spain. Plant Dis 85: 445 .

46. Haider MS, Tahir M, Latif S and Briddon RW (2006) First report of Tomato leaf curl New Delhi virus infecting Eclipta prostrata in Pakistan. J Phytopathol 55 285-285.

47. Mehrotra RS (1991) Plant Pathology. (8thedn) Tata McGraw Hill-publishing New Delhi.

48. Du Toit (1948) The control of spotted wilt tomato. Farming S Africa 23: 786-788

49. Bradbent L, Burt PE, Heathcote CD (1956) The control of potato viruses by insecticides. Ann Appl Biol 44: 256-273.

50. Verma HN, Awasthi LP (1980) Can J Bot 58: 2141-2144.

51. Verma HN (1985) Nature of plant virus inhibitors present in certain plants. In â€œPerspectives in plant virologyâ€. BM Gupta, BP Singh, HN Verma and KM Srivastava (Eds.), Print House (India), Lucknow. 133-152.

52. Verma HN (1996) Biochem. Cell Biol 86; 485-492.

53. Andrade H, Garcia E, Mora A, Nieto D, Villawveva A (1995) Integrated management of Papaya ringspot virus in Vera Cruz, Mexico. Trop Fru Newslett 14: 7 .

54. Rezende JAM, Costa AS (1995) Alternatives for integrated control of Papaya ringspot virus. Acta Horticult 370: 129-132.

55. Singh S, Awasthi LP (2002) Prevention of infection and spread of bean common mosaic virus disease of mungbean and urdbean through botanicals. Indian $J$ Mycol PI Pathol 32: 141.

56. Kumar P, Awasthi LP (2003) Management of infection and spread of bottle gourd mosaic virus disease in bottle gourd through botanicals. Indian Phyotopathol 56: 361.

57. Kunkalikar S, Byadgi AS, Kulkarni VR, Reddy MK (2006) Management of Papaya ring spot virus disease. Indian J Virol 17: 39-43.

58. Khan MS, Raj SK, Singh R (2006) First report of Tomato leaf curl New Delhi virus infecting chili in India. Plant Pathol 55: 289.

59. Somvanshi P, Khan MS, Raj SK, Seth PK (2009) Ageratum conizoides and Parthenium hystorophorous: Alternate hosts of Begomovirus and Phytoplasma. International day for Biological diversity, Invasive Alien Species, Souvenir 4445.

60. Fraser RSS (1990) The genetics of resistance to plant viruses. Ann Rev Phytopathol 28: 179-200.

61. Pelham J, Fletcher JT, Hawkins JH (1970) The establishment of a new strain of tobacco mosaic virus resulting from the use of resistant varieties of tomato. Ann Appl Biol 75: 293.

62. Grumet $R$ (1994) Development of virus resistant plants via genetic engineering Plant Breed Rev 12: 47-79.

63. Ji Y, Scott JW, Hanson P, Graham E, Maxwell DP (2007b) Sources of resistance, inheritance, and location of genetic loci conferring resistance to members of the tomato-infecting begomoviruses. In: Czosnek $\mathrm{H}$, ed. Tomato Yellow Leaf Curl Virus Disease: Management, Molecular Biology, Breeding for Resistance. Dordrecht, The Netherlands: Springer, 343-62.

64. Zamir D, Ekstein-Michelson I, Zakay Y, Navot N, Zeidan M, et al. (1994) Mapping and introgression of a tomato yellow leaf curl virus tolerance gene, TY-1. Theor Appl Genet 88: 141-146.

65. Chague V, Mercier JC, Guenard M, de Courcel A, Vedel F (1997) Identification of RAPD markers linked to a locus involved in quantitative resistance to TYLCV in tomato by bulked segregant analysis. Theoret App Genet 95: 671-677.

66. Hanson PM, Bernacchi D, Green S (2000) Mapping a wild tomato introgression associated with tomato yellow leaf curl virus resistance in a cultivated tomato line. J American So Hort Sci 125: 15-20.

67. Ji Y, Schuster DJ, Scott JW (2007a) Ty-3, a begomovirus resistance locus near the Tomato yellow leaf curl virus resistance locus Ty-1 on chromosome 6 of tomato. Mol Breed 20: 271-284. 
Citation: Snehi SK, Raj SK, Prasad V, Singh V (2015) Recent Research Findings Related to Management Strategies of Begomoviruses. J Plant Pathol Microb 6: 273. doi:10.4172/2157-7471.1000273

68. Verlaan MG, Hutton SF, Ibrahem RM, Kormelink R, Visser RG, et al. (2013) The Tomato Yellow Leaf Curl Virus resistance genes Ty-1 and Ty-3 are allelic and code for DFDGD-class RNA-dependent RNA polymerases. PLoS Genet 9: e1003399.

69. Ji Y, Scott JW, Schuster DJ, Maxwell DP (2009) Molecular mapping of Ty-4, a tomato yellow leaf curl virus resistance locus on chromosome 3 of tomato. $J$ American So Hort Sci 134, 281-8.

70. Hutton SF, Scott JW, Schuster DJ (2012) Recessive resistance to tomato yellow leaf curl virus from the tomato cultivar Tyking is located in same region as Ty-5 on chromosome 4. J American So Hort Sci 47: 324-327.

71. Anbinder I, Reuveni M, Azari R, Paran I, Nahon S, et al. (2009) Molecular dissection of Tomato leaf curl virus resistance in tomato line TY172 derived from Solanum peruvianum. Theor Appl Genet 119: 519-530.

72. Barbieri M, Acciarri N, Sabatini E, Sardo L, Accotto GP, Pecchioni N (2010) Introgression of resistance to two Mediterranean virus species causing tomato yellow leaf curl into a valuable traditional tomato variety. J Plant Pathol 92: $485-493$

73. Kelly JD, Afanador L, Haley SD (1995) Pyramiding genes for resistance to Bean common mosaic virus. Euphytica 82: 207-12.

74. Caranta C, Palloix A, Gebre-Selassie K, Lefebvre V, Moury B, et al. (1996) A complementation of two genes originating from susceptible Capsicum annuum lines confers a new and complete resistance to pepper veinal mottle virus. Phytopathol 86: 739-743.

75. Werner K, Friedt W, Ordon F (2005) Strategies for pyramiding resistance genes against the barley yellow mosaic virus complex (BaMMV, BaYMV, BaYMV-2). Mol Breeding 16: 45-55.

76. Shi A, Chen P, Li DX, Zheng C, Hou A, et al. (2008) Genetic confirmation of 2 independent genes for resistance to soybean mosaic virus in $\mathrm{J} 05$ soybean using SSR markers. J Hered 99: 598-603.

77. Yang L, Wang W, Yang W, Wang M (2013) Marker-assisted selection for pyramiding the waxy and opaque-16 genes in maize using cross and backcross schemes. Mol Breed31: 767-75

78. Kadirvel P, de la Pana R, Schaffeitner R (2013) Mapping of QTLs in tomato line FLA456 associated with resistance to a virus causing yellow leaf curl disease. Euphytica 190: 297-308.

79. Prasanna HC, Sinha DP, Rai GK, Krishna R, Kashyap SP, et al. (2014) Pyramiding Ty-2 and Ty-3 genes for resistance to monopartite and bipartite tomato leaf curl viruses of India. Plant Pathol Doi: 10.1111/ppa.12267.

80. Gasser CS, Fraley RT (1989) Genetically engineering plants for crop improvement. Science 244: 1293-1299.

81. Abel PP, Nelson RS, De B, Hoffmann N, Rogers SG, et al. (1986) Delay of disease development in transgenic plants that express the tobacco mosaic virus coat protein gene. Science 232: 738-743

82. Horsch RB, Fry JE, Hoffmann NL, Eichholtz D, Rogers SG, et al. (1985) A simple and general method for transferring genes to plants. Science 227: 12291231.

83. Beachy RN, Loesch-Fries S, Tumer NE (1990) Coat protein-mediated resistance against virus infection. Ann Rev Phytopathol 28: 451-74.

84. Wilson TM (1993) Strategies to protect crop plants against viruses: pathogenderived resistance blossoms. Proc Natl Acad Sci U S A 90: 3134-3141.

85. Baulcombe D (1994) Replicase-mediated resistance: a novel type of virus resistance in transgenic plants? Trends Microbiol 2: 60-63.

86. Lomonossoff GP (1995) Pathogen-derived resistance to plant viruses. Annu Rev Phytopathol 33: 323-343

87. Pappu HR, Niblett CL, Lee RF (1995) Application of recombinant DNA technology to plant protection: molecular approaches to engineering virus resistance in crop plants. World J Microbiol Biotechnol 11: 426-437.

88. Varma A (1997) Application of biotechnology in plant pest management:curren status and future prospects. In â€œProceedings of regional expert consultation on application of biotechnology in plant pest managementâ€, FAO, RAP publication, Bangkok. 21-66.

89. Prins M, Goldbach R (1998) The emerging problem of tospovirus infection and nonconventional methods of control. Trends Microbiol 6: 31-35.

90. Reimann-Phillipp U (1998) Mechanism of resistance: Expression of coat protein. In. Methods in molecular biology, Plant virology protocols:From virus isolation to transgenic resistance. (Eds.) GD Foster and SC Taylor). Human press Inc., Totowa, NJ. Vol. 81

91. Bendahmane M, Beachy RN (1999) Control of tobamovirus infections via pathogen-derived resistance. Adv Virus Res 53: 369-386.

92. Jain RK, Varma A (2000) Biotechnological management of viral diseases of plants. In: Trivedi PC (eds) Plant Diseases Pointer publishers, Jaipur, India 1-20.

93. Callaway A, Giesman-Cookmeyer D, Gillock ET, Sit TL, Lommel SA (2001) The multifunctional capsid proteins of plant RNA viruses. Annu Rev Phytopathol 39: 419-460.

94. Varma A, Jain RK, Bhat Al (2002) Virus resistant transgenic plants for environmentally safe management of Viral Diseases. Indian J Biotechnol 1 : 73-86.

95. Gonsalves D, Slightom JL (1993) Coat-protein mediated protection:Analysis of transgenic plants for resistance in a variety of crops. Seminars Virol 4: 397-406

96. Hamilton RI (1980) In: Viruses. Plant Disease: An Advanced Treatise. Academic Press, NY. 5: 279.

97. Palukaitis P, Zaitlin M (1997) Replicase-mediated resistance to plant virus disease. Adv Virus Res 48: 349-377.

98. Beachy RN (1993) Transgenic resistance to plant viruses. Seminars Virol 4 739-769.

99. Hull R (1994) Resistance to plant viruses: Obtaining genes by non-conventional approaches. Euphytica 75: 195-205.

100. Baulcombe DC (1994b) Novel strategies for engineering virus resistance in plants. Curr Opin Biotechnol 5: 117-124.

101. Nelson RS, McCormick SM, Delannay X, Dube P, Layton J, et al. (1988) Virus tolerance, plant growth, and field performance of transgenic tomato plants expressing coat protein from tobacco mosaic virus. Bio-Technol 6: 403-409.

102. Sanders PR, Sammons B, Kaniewski W, Haley L, Layton J, et al. (1992) Field resistance of transgenic tomatoes expressing the tobacco mosaic virus or tomato mosaic virus coat protein genes. Phytopathol 82: 683-690.

103. Namba S, Ling KS, Gonsalves C, Gonsalves D, Slightom JL (1991) Expression of the gene encoding the coat protein of cucumber mosaic virus (CMV) strain $\mathrm{WL}$ appears to provide protection to tobacco plants against infection by several different CMV strains. Gene 107: 181-188.

104. Quemada HD, Gonsalves D, Slightom JL (1991) Expression of coat protein gene rom cucumber mosaic virus strain $C$ in tobacco:protection against infection by CMV strains transmitted mechanically and by aphids. Phytopathology 81: 749 .

105. Fuchs M, Provvidenti R, Slightom JL, Gonsalves D (1996) Evaluation of transgenic tomato plants expressing the coat protein gene of cucumber mosaic virus strain WL under field condition. Plant Dis 80: 270-275.

106. Loesch-Fries LS, Merlo D, Zinnen T, Burhop L, Hill K, et al. (1987) Expression of alfalfa mosaic virus RNA 4 in transgenic plants confers virus resistance. EMBO J 6: 1845-1851.

107. Tumer NE, O'connell KM, Nelson RS, Sanders PR, Beachy RN, et al. (1987) Expression of alfalfa mosaic virus coat protein gene confers cross-protection in transgenic tobacco and tomato plants. EMBO J 6: 1181-1188.

108. Hemenway C, Fang RX, Kaniewski WK, Chua NH, Tumer NE (1988) Analysis of the mechanism of protection in transgenic plants expressing the potato virus $X$ coat protein or its antisense RNA. EMBO J 7: 1273-1280.

109. Perlak F, Kaniewski W, Lawson C, Vincent M, Feldman J (1994) Genetically improved potatoes: Their potential role in integrated pest management. In Proc. 3rd EFPP Conference. M. Manka (Eds.). J Phytopathol 451-454.

110. Kaniewski WK, Thomas PE (1993) Field testing of virus resistant transgenic plants. Semi Virol 4: 389-396.

111. Kunik T, Salomon R, Zamir D, Navot N, Zeidan M, et al. (1994) Transgenic tomato plants expressing the tomato yellow leaf curl virus capsid protein are resistant to the virus. Biotechnology (N Y) 12: 500-504.

112. Wisniewski LA, Powell PA, Nelson RS, Beachy RN (1990) Local and systemic spread of tobacco mosaic virus in transgenic tobacco. Plant Cell 2: 559-567.

113. Hayakawa T, Zhu Y, Itoh K, Kimura Y, Izawa T, et al. (1992) Genetically 
Citation: Snehi SK, Raj SK, Prasad V, Singh V (2015) Recent Research Findings Related to Management Strategies of Begomoviruses. J Plant Pathol Microb 6: 273. doi:10.4172/2157-7471.1000273

Page 11 of 12

engineered rice resistant to rice stripe virus, an insect-transmitted virus. Proc Natl Acad Sci U S A 89: 9865-9869.

114. Osbourn JK, Watts JW, Beachy RN, Wilson TM (1989) Evidence that nucleocapsid disassembly and a later step in virus replication are inhibited in transgenic tobacco protoplasts expressing TMV coat protein. Virology 172 370-373.

115. Register JC 3rd1, Beachy RN (1988) Resistance to TMV in transgenic plants results from interference with an early event in infection. Virology 166: 524532.

116. van Dun CM, Bol JF, Van Vloten-Doting L (1987) Expression of alfalfa mosaic virus and tobacco rattle virus coat protein genes in transgenic tobacco plants. Virology 159: 299-305

117. Powell PA, Sanders PR, Tumer N, Frailey RT, Beachy RN (1990) Protection against tobacco mosaic virus infection in transgenic tobacco plants requires accumulation of coat protein rather than coat protein RNA sequences. Viro 175: 1240130

118. English JJ, Mueller E, Baulcombe DC (1996) Suppression of Virus Accumulation in Transgenic Plants Exhibiting Silencing of Nuclear Genes. Plant Cell 8: 179-188.

119. Baulcombe DC (1996) Mechanisms of Pathogen-Derived Resistance to Viruses in Transgenic Plants. Plant Cell 8: 1833-1844.

120. Mueller E, Gilbert JE, Davenport G, Brigneti G, Baulcombe DC (1995) Homology-dependent resistance: transgenic virus resistance in plants related to homology-dependent gene silencing. Plant J 7: 1001-1013.

121. Waterhouse PM, Wang MB, Lough T (2001) Gene silencing as an adaptive defence against viruses. Nature 411: 834-842.

122. Lawson C, Kaniewski W, Haley L, Rozman R, Newell C, Sanders P, Tumer NE (1990) Engineering resistance to mixed virus infection in a commercial potato cultivar:Resistance to potato virus $\mathrm{X}$ and potato virus $\mathrm{Y}$ in transgenic Russe Burbank. Bio-Technol 8: 127-134.

123. Farinelli L, Malnoe $P$, Collet GF (1992) Heterlogous encapsidation of potato virus strain O (PVYO) with the transgenic coat protein of PVY strain N (PVYN) in Solanum tuberosum cv. Bintje. Bio-Technol 10: 1020-1025.

124. Barker H, Reavy B, Kumar A, Webster KD, Mayo MA (1992) Restricted virus multiplication on potato transformed with the coat protein gene of potato leafroll luteovirus:similarities with a type of host gene mediated resistance. Ann Appl Biol 120: 55-64.

125. Vanderschuren $H$, Akbergenov R, Pooggin MM, Hohn T, Gruissem W, et al (2007) Transgenic cassava resistance to African cassava mosaic virus is enhanced by viral DNA-A bidirectional promoter-derived siRNAs. Plant Mol Biol 64: 549-557.

126. Bonfim K, Faria JC, Nogueira EO, Mendes EA, Aragão FJ (2007) RNAimediated resistance to Bean golden mosaic virus in genetically engineered common bean (Phaseolus vulgaris). Mol Plant Microbe Interact 20: 717-726.

127.Pakniat-Jahromy A, Behjatnia SA, Dry IB, Izadpanah K, Rezaian MA (2010) A new strategy for generating geminivirus resistant plants using a DNA betasatellite/split barnase construct. J Virol Methods 170: 57-66.

128. Wintermantel WM, Banerjee N, Oliver JC, Paolillo DJ, Zaitlin M (1997) Cucumber mosaic virus is restricted from entering minor veins in transgenic tobacco exhibiting replicase-mediated resistance. Virology 231: 248-257.

129. Golemboski DB, Lomonossoff GP, Zaitlin M (1990) Plants transformed with a tobacco mosaic virus nonstructural gene sequence are resistant to the virus. Proc Natl Acad Sci U S A 87: 6311-6315.

130. Hong Y, Stanley J (1996) Virus resistance in Nicotiana benthamiana conferred by African cassava mosaic virus replication associated $(\mathrm{ACl})$ transgene. Mol Plant Micro Interact 9: 219-225.

131. Noris E, Accotto GP, Tavazza R, Brunetti A, Crespi S, et al. (1996) Resistance to tomato yellow leaf curl geminivirus in Nicotiana benthamiana plants transformed with a truncated viral C1 gene. Virology 224: 130-138.

132. Tenllado F, Garcia-Luque I, Serra MT, Diaz-Ruiz JR (1995) Nicotiana benthamiana plants transformed with the $54-\mathrm{kDa}$ region of the pepper mild mottle tobamovirus replicase gene exhibit two types of resistance responses against viral infection. Virol 211: 170-183.

133.Zaitlin M, Anderson JM, Perry KL, Zhang L, Palukaitis P (1994) Specificity of replicase-mediated resistance to cucumber mosaic virus. Virology 201: 200205.

134. Hellwald KH, Palukaitis P (1994) Nucleotide sequence and infectivity of cucumber mosaic cucumovirus (strain K) RNA2 involved in breakage of replicase-mediated resistance in tobacco. J Gen Virol $75: 2121-2125$.

135.Longstaff M, Brigneti G, Boccard F, Chapman S, Baulcombe D (1993) Extreme resistance to potato virus $\mathrm{X}$ infection in plants expressing a modified component of the putative viral replicase. EMBO J 12: 379-386.

136. Audy P, Palukaitis P, Slack SA, Zaitlin M (1994) Replicase-mediated resistance to potato virus $Y$ in transgenic tobacco plants. Mol Plant Microbe Interact 7: 15-22.

137. Brederode FT, Taschner PE, Posthumus E, Bol JF (1995) Replicase-mediated resistance to alfalfa mosaic virus. Virology 207: 467-474

138. Carr JP, Zaitlin M (1991) Resistance in transgenic tobacco plants expressing a nonstructural gene sequence of tobacco mosaic virus is a consequence of markedly reduced virus replication. Mol Plant Microbe Interact 4: 579-585.

139. Rubino L, Russo M (1995) Characterization of resistance to cymbidium ringspot virus in transgenic plants expressing a full-length viral replicase gene. Virology 212: 240-243

140. Mushegian AR, Koonin EV (1993) Cell-to-cell movement of plant viruses Insights from amino acid sequence comparisons of movement proteins and from analogies with cellular transport systems. Arch Virol 133: 239-257.

141. Wolf S, Deom CM, Beachy RN, Lucas WJ (1989) Movement protein of tobacco mosaic virus modifies plasmodesmatal size exclusion limit. Science 246: 377-379.

142. Deom CM, Schubert KR, Wolf S, Holt CA, Lucas WJ, et al. (1990) Molecular characterization and biological function of the movement protein of tobacco mosaic virus in transgenic plants. Proc Natl Acad Sci U S A 87: 3284-3288.

143. Cooper B, Lapidot M, Heick JA, Allan DJ, Beachy RN (1995) A defective movement protein of TMV in transgenic plants confers resistance to multiple viruses whereas the functional analog increases susceptibility. Virol 206: 307 313.

144. Tacke E, Salamini F, Rohde W (1996) Genetic engineering of potato for broadspectrum protection against virus infection. Nat Biotechnol 14: 1597-1601.

145. Harrison B D, Mayo MA, Baulcombe DC (1987) Virus resistance in transgenic plants that express cucumber mosaic virus satellite RNA. Nature 328: 799802.

146. Gerlach WL, Llewellyn D, Haseloff J (1987) Construction of a disease resistance gene using the satellite RNA of tobacco ringspot virus. Nature 328: 802-806.

147. Smith CR, Tousignant ME, Geletka LM, Kaper JM (1992) Competition between cucumber mosaic virus satellite RNAs in tomato seedlings and protoplasts: A model for satellite-mediated control of tomato necrosis. Plant Dis 76: 12701274

148. Maiti IB, Murphy JF, Shaw JG, Hunt AG (1993) Plants that express a potyvirus proteinase gene are resistant to virus infection. Proc Natl Acad Sci U S A 90 $6110-6114$

149. Vardi E, Sela I, Edelbaum O, Livneh O, Kuznetsova L, et al. (1993) Plants transformed with a cistron of a potato virus $\mathrm{Y}$ protease (Nla) are resistant to virus infection. Proc Natl Acad Sci U S A 90: 7513-7517.

150. Gutierrez C (2002) Strategies for geminivirus DNA replication and cell cycle interference. Phys Mol Plant Pathol 60: 219-230.

151.Leclerc D, AbouHaidar MG (1995) Transgenic tobacco plants expressing a truncated form of the PAMV capsid protein (CP) gene show CP-mediated resistance to potato aucuba mosaic virus. Mol Plant Microbe Interact 8: 58-65.

152. Yepes LM, Fusch M, Slightom JL, Gonsalves D (1996) Sense and antisense coat protein gene constructs confer high levels of resistance to tomato ringspot nepovirus in transgenic Nicotiana species. Phytopathol 86: 417-424.

153. Atkins D, Young M, Uzzell S, Kelly L, Fillatti J, et al. (1995) The expression of antisense and ribozyme genes targeting citrus exocortis viroid in transgenic plants. J Gen Virol 76 : 1781-1790.

154. de Feyter R, Young M, Schroeder K, Dennis ES, Gerlach W (1996) A ribozyme gene and an antisense gene are equally effective in conferring resistance to tobacco mosaic virus on transgenic tobacco. Mol Gen Genet 250: 329-338. 
Citation: Snehi SK, Raj SK, Prasad V, Singh V (2015) Recent Research Findings Related to Management Strategies of Begomoviruses. J Plant Pathol Microb 6: 273. doi:10.4172/2157-7471.1000273

155. Han S, Wu Z, Yang H, Wang R, Yie Y, et al. (2000) Ribozyme-mediated resistance to rice dwarf virus and the transgene silencing in the progeny of transgenic rice plants. Transgenic Res 9: 195-203.

156. Napoli C, Lemieux C, Jorgensen R (1990) Introduction of a Chimeric Chalcone Synthase Gene into Petunia Results in Reversible Co-Suppression of Homologous Genes in trans. Plant Cell 2: 279-289.

157. Cogoni C, Macino G (1997) Isolation of quelling-defective (qde) mutants impaired in posttranscriptional transgene-induced gene silencing in Neurospora crassa. Proc Natl Acad Sci U S A 94: 10233-10238.

158. Cogoni C, Irelan JT, Schumacher M, Schmidhauser TJ, Selker EU, et al. (1996) Transgene silencing of the al-1 gene in vegetative cells of Neurospora is mediated by a cytoplasmic effector and does not depend on DNA-DNA interactions or DNA methylation. EMBO J 15: 3153-3163.

159. Fire A, Xu S, Montgomery MK, Kostas SA, Driver SE, et al. (1998) Potent and specific genetic interference by double-stranded RNA in Caenorhabditis elegans. Nature 391: 806-811

160. Vanitharani R, Chellappan P, Pita JS, Fauquet CM (2004) Differential roles of AC2 and AC4 of cassava geminiviruses in mediating synergism and suppression of posttranscriptional gene silencing. J Virol 78: 9487-9498.

161.Bisaro DM (2006) Silencing suppression by geminivirus proteins. Virology 344: $158-168$

162. Hamilton AJ, Baulcombe DC (1999) A species of small antisense RNA in posttranscriptional gene silencing in plants. Science 286: 950-952.

163. Day AG, Bejarano ER, Buck KW, Burrell M, Lichtenstein CP (1991) Expression of an antisense viral gene in transgenic tobacco confers resistance to the DNA virus tomato golden mosaic virus. Proc Natl Acad Sci U S A 88: 6721-6725.

164. Bendahmane M, Gronenborn B (1997) Engineering resistance against tomato yellow leaf curl virus (TYLCV) using antisense RNA. Plant Mol Biol 33: 351 357.

165.Raj SK, Singh R, Pandey SK, Singh BP (2005) Agrobacterium-mediated tomato transformation and regeneration of transgenic lines expressing Tomato leaf curl virus coat protein gene for resistance against TLCV infection. Curr Sci 88: 1675-1679.

166. Shivaprasad PV, Thomas M, Balamani V, Biswas D, Vanitharani R, et al (2006) Factors contributing to deletion within Mungbean yellow mosaic virus partial dimers in binary vectors used for agroinoculation. J Virol Methods 137: 72-81.

167. Sunitha S, Marian D, Hohn B, Veluthambi K (2011) Antibegomoviral activity of the agrobacterial virulence protein VirE2. Virus Genes 43: 445-453.

168. Yadav RK, Chattopadhyay D (2011) Enhanced viral intergenic region-specific short interfering RNA accumulation and DNA methylation correlates with resistance against a geminivirus. Mol Plant Microbe Interact 24: 1189-1197.

169. Saxena S, Singh N, Ranade SA, Babu SG (2011) Strategy for a generic resistance to geminiviruses infecting tomato and papaya through in silico siRNA search. Virus Genes 43: 409-434.

170. Kasrawi MA, Suwwan MA, Mansour A (1988) Sources of resistance to tomato yellow leaf curl virus in Lycopersicon species. Euphytica 37: 61-64.

171.Zakay Y, Navot N, Zeidan M, Kedar N, Rabinowitch H, Czosnek H, Zamir D (1991) Screening Lycopersicon accessions for resistance to tomato yellow leaf curl virus: presence of viral DNA and symptom development. Plant Dis 75: 279-281.

172. Michelson I, Zamir D, Czosnek H (1994) Accumulation and translocation of Tomato yellow leaf curl virus (TYLCV) in a Lycopersicon esculentum breeding line containing the L. chilense TYLCV tolerance gene Ty-1. Phytopathol 84: 928-933.

173.Pic $\tilde{A}^{3} B$, DÃez MJ, Nuez F (1998) Evaluation of whitefly-mediated inoculation techniques to screen Lycopersicon esculentum and wild relatives for resistance to Tomato yellow leaf curl virus. Euphytica 101: 259-271.
174. Vidavsky F, Czosnek H (1998) Tomato Breeding Lines Resistant and Tolerant to Tomato Yellow Leaf Curl Virus Issued from Lycopersicon hirsutum. Phytopathology 88: 910-914.

175. Piven NM, UzcÃ jtegui R (1995) Resistance to mosaic virus in species of Lycopersicon. Plant Dis 79: 590-594.

176. Ferreira PTO, Bezerra IC, Villas BÃ'as GL, Ribeiro SG, Giordano LB (1999) AvaliaÃß̃̃£o de fontes de resist $\tilde{A}^{a}$ ncia a isolado de geminivÃrus com genoma bipartido transmitido por Bemisia argentifolii em Lycopersicon spp. Fitopato Bras 24: 131-135

177. Santana FM, Ribeiro SG, Moita AW., Moreira JR, DJ, Giordano LB (2001) Sources of resistance in Lycopersicon spp. to a bipartite whitefly-transmitted geminivirus from Brazil. Euphytica 122: 45-51.

178. Praveen S, Kushwaha CM, Mishra AK, Singh V, Jain RK, Varma A (2005a) Engineering tomato for resistance to tomato leaf curl disease using viral rep gene sequences. Plant Cell Tiss Org Cult 83: 311-318.

179.Praveen S, Mishra AK, Dasgupta A (2005b) Antisense suppression of replicase gene expression recovers tomato plants from leaf curl infection. Plant Sci 168: 1011-1014.

180. Singh AK, Praveen S, Singh BP, Varma A, Arora N (2009) Safety assessment of leaf curl virus resistant tomato developed using viral derived sequences. Transgenic Res 18: 877-887.

181. Ramesh SV, Mishra AK, Praveen S (2007) Hairpin RNA-mediated strategies for silencing of tomato leaf curl virus $A C 1$ and AC4 genes for effective resistance in plants. Oligonucleotides 17: 251-257.

182. Pandey P, Choudhury NR, Mukherjee SK (2009) A geminiviral amplicon (VA) derived from Tomato leaf curl virus (ToLCV) can replicate in a wide variety of plant species and also acts as a VIGS vector. Virol J 6: 152

183. Akbergenov R, Si-Ammour A, Blevins T, Amin I, Kutter C, et al. (2006) Molecular characterization of geminivirus-derived small RNAs in different plant species. Nucleic Acids Res 34: 462-471.

184. Chellappan P, Vanitharani R, Pita J, Fauquet CM (2004) Short interfering RNA accumulation correlates with host recovery in DNA virus-infected hosts, and gene silencing targets specific viral sequences. J Virol 78: 7465-7477.

185. Azhar MT, Amin I, Anjum Zl, Arshad M, Briddon RW, et al. (2010) Both malvaceous and non-malvaceous betasatellites are associated with two wild cotton species grown under field conditions in Pakistan. Virus Genes 41: 417 424.

186. Amin I, Hussain K, Akbergenov R, Yadav JS, Qazi J, et al. (2011) Suppressors of RNA silencing encoded by the components of the cotton leaf cur begomovirus-betasatellite complex. Mol Plant Microbe Interact 24: 973-983.

187. Cui X, Li G, Wang D, Hu D, Zhou X (2005) A Begomovirus DNAbeta-encoded protein binds DNA, functions as a suppressor of RNA silencing, and targets the cell nucleus. J Virol 79: 10764-10775.

188. Gopal P Pravin Kumar P Sinilal B, Jose J, Kasin Yadunandam A et al. (2007) Differential roles of C4 and betaC1 in mediating suppression of posttranscriptional gene silencing: evidence for transactivation by the $\mathrm{C} 2$ of Bhend yellow vein mosaic virus, a monopartite begomovirus. Virus Res 123: 9-18.

189. Sharma $P$, Ikegami M, Kon T (2010) Identification of the virulence factors and suppressors of posttranscriptional gene silencing encoded by Ageratum yellow vein virus, a monopartite begomovirus. Virus Res 149: 19-27.

190. Yang X, Guo W, Ma X, An Q, Zhou X (2011) Molecular characterization of tomato leaf curl China virus, infecting tomato plants in China, and functional analyses of its associated betasatellite. Appl Environ Microbiol 77: 3092-3101.

191. Tiwari N, Sharma PK, Malathi VG (2013) Functional characterization of $\hat{I}^{2} \mathrm{C} 1$ gene of Cotton leaf curl Multan betasatellite. Virus Genes 46: 111-119.

192. Eini O, Dogra SC, Dry IB, Randles JW (2012) Silencing suppressor activity of a begomovirus DNA $\hat{I}^{2}$ encoded protein and its effect on heterologous helper virus replication. Virus Res 167: 97-101. 